\title{
Does Community Clustering Mitigate the Negative Effect Of Poverty on Adolescent Condom Use in South Africa?
}

\begin{abstract}
CONTEXT: It is important to examine whether youth from disadvantaged households are less likely than others to use a condom at first sex, even after correcting for shared characteristics within communities.

METHODS: Baseline survey data from the Transitions to Adulthood in the Context of AIDS in South Africa study in KwaZulu-Natal were used. Random effects logistic regression assessed the relationship between poverty and 14-22year-olds' use of condoms at first sex, correcting for shared characteristics of adolescents within each community.
\end{abstract}

RESULTS: Twenty-three percent of young people had used a condom at first sex. Poor and extremely poor females had about one-third the odds of nonpoor females of using a condom at first sex, even after adjusting for community clustering; among males; however, there was no association between poverty and condom use, after adjusting for background factors and community clustering.

CONCLUSIONS: The importance of community clustering of neighborhood-level characteristics differs by gender in South Africa. Poverty remains a central risk factor for HIV among young women, regardless of the surrounding context, but not among men.

International Family Planning Perspectives, 2008, 34(3):121-126.
By Amara L. Robinson and Eric E.Seiber

Amara L. Robinson is an independent consultant, and Eric E. Seiber is assistant professor, Division of Health Services Management and Policy, College of Public Health, Ohio State University, Columbus, Ohio, USA
Young women in South Africa face an especially daunting transition into adulthood. At the current rate of infection, one in every three will be HIV-positive by age 21. ${ }^{1}$ A 2005 nationally representative HIV prevalence study among 15-24-year-olds in South Africa documented an abrupt rise in HIV prevalence among young women: Although only $4 \%$ of women 15-19 were HIV-positive, more than one-third of women were infected by age $21 .^{2}$ A study conducted in 2000 among university students in KwaZuluNatal-the site of this investigation-found that $26 \%$ of women and $12 \%$ of men aged 20-24 were already HIVpositive. ${ }^{3}$ These data underscore the urgent need to identify HIV risk factors for young women that are either not known, not being effectively addressed or both.

It has been widely argued that women bear the brunt of HIV worldwide because of their positions of low social, political and economic power-all of which can be considered types of poverty. 1,2,4 Gender differences in economic status among South Africans support the hypothesis that poverty disproportionately increases women's risk of acquiring HIV over that of men. As many as $60 \%$ of South African households are chronically poor, ${ }^{*}$ and women within these households may be affected more than men. ${ }^{5}$ For example, greater proportions of women than of men, regardless of racial group, are economically inactive (defined as being 15 years or older and available to work, but

*According to the most recent Income and Expenditure of Households Statistical Release, the average annual income of a South African household was 74,589 rand (US\$9,550). The average drops to 37,711 rand (US\$4,829) for black African households. currently not working). Similarly, women are more likely than men to be unemployed, regardless of their educational attainment. ${ }^{6}$

Much of the literature examining the link between poverty and various health and developmental outcomes suggests a broad base of risk beyond that which can be captured by income-based measures alone..$^{7-10}$ In the last decade, many studies-primarily conducted in the United States-have examined neighborhood effects on healthrelated outcomes among youth. Findings from such studies suggest that elements within the broader social and economic context of communities are associated with various developmental outcomes for youth, even after controlling for family- and individual-level characteristics, including family economic status. ${ }^{11-15}$

Although a growing body of evidence suggests an association between community context and youth development, there remains a paucity of research on the social context of HIV/AIDS, especially in developing countries. A common thread in most current literature on research concerning HIV/AIDS and youth, however, is the need to explore and identify a model of behavior change that is not focused solely on the individual. Recent studies, both quantitative and qualitative, describe an intricate net of factors at various levels of adolescents' lives that influence their actions, including young people's sexual risk-taking behaviors. ${ }^{2,16-18}$ Perhaps more important, many of these studies have emphasized the heterogeneity of behaviors within a given adolescent population and the fact that very little is known about what factors at which levels are re- 
sponsible for the marked differences. This includes the finding that although youth living in disadvantaged settings are generally more likely than others to engage in risk-taking behaviors, there are exceptions.

The purpose of the current study is to determine whether factors common across a community contribute to the observed phenomenon that some teenagers coming from an impoverished background are exceptions and do not engage in high-risk behaviors. Specifically, would correcting for adolescents' clustering in communities mitigate the observed negative effect of poverty on young women's likelihood of using a condom at first sex and therefore, their subsequent risk of HIV infection? We address this question using data from the 1999 baseline survey conducted as part of the Transitions to Adulthood in the Context of AIDS in South Africa study conducted in KwaZulu-Natal

\section{METHODS}

Data

The baseline data collection for the study utilized a modified multistage cluster sample design approach. ${ }^{19}$ First, 120 enumeration areas were randomly selected using a sampling frame of all enumeration areas contained within two administrative areas (Durban Metropolitan and Mtunzini Magisterial) in the province of KwaZulu-Natal. Each enumeration area was divided into approximately equal segments, to assure an equal probability of selection and to eliminate the need for a complete sampling frame listing all households. Two rural enumeration areas were excluded from the survey due to the inability of field workers to gain permission from area leaders and secure their safety for the survey work, leaving a total of 118. In each enumeration area, a segment was randomly chosen, from which all households were surveyed; segment size was determined on the basis of census data on the number of households.

Fieldwork was conducted during a six-week period in 1999. First, interviews were conducted in 1,974 households. Interviewers were instructed to identify the responsible adult of the household and to not interview anyone under the age of 16 . Household data were collected from the head of household or his or her spouse in $62 \%$ of the cases; about $25 \%$ of respondents were a son or daughter of the head of household, and the remainder were other relatives. The survey asked questions about the education and work history of all household members, traumatic family events in the past two years (e.g., death, injury, illness, loss of funds and business failure), household wealth or assets, government assistance and monthly expenditure on food and nonfood items.

Youth aged 14-22 from the selected households were eligible to participate in the adolescent survey, which asked about their social and demographic characteristics, education and work history, HIV/AIDS knowledge, risk perception and stigma, sexual experience and knowledge, condom use and reproductive history. Overall, 90\% of black African youth and 68\% of white youth identified in the selected households were interviewed. The average number of interviews per enumeration area was 33, with a minimum number of three and a maximum of 64 .

\section{Analysis}

For our analysis, we constructed a measure of household poverty based on three indicators of household expenditure or consumption: total monthly household expenditure on food, nonfood items and rent. Because the responses to the three household expenditure questions that formed the household poverty categories were comprised of a range of values, the variables were first transformed into values reflecting the lowest value of each range. This resulted in poverty categories that reflected proportions of nonpoor and poor respondents almost identical to those in the 1996 Census. ${ }^{20}$ We calculated per capita spending by totaling the household expenditures and dividing by the number of persons per household. We defined poor households as those with monthly per capita spending of 250 rand (approximately US\$31.63) or less, in accordance with the poverty line defined by Stats South Africa. ${ }^{5,6}$ Furthermore, we defined a lower limit of the poor households by dividing the poverty line in half, creating an "extremely poor" category comprising households with monthly per capita expenditures of 125 rand (approximately US\$15.81) or less.

We included only sexually experienced youth in our analytic sample ( $\mathrm{N}=1,178)$. We conducted bivariate and multivariate analyses to investigate young people's use of a condom at sexual debut. Of the studies that have looked at the effect of neighborhood characteristics on condom use in the United States, the use of a condom at first and last sex have been the outcomes most often examined. ${ }^{21-23}$ Our analysis follows a related study conducted by Kaufman et al., which used the same data set to look at adolescent reproductive health outcomes in relation to their surrounding context. ${ }^{18}$

We used three models to examine the influence of adolescents' shared socioeconomic backgrounds in the same community or "clustering" on the relationship between poverty and condom use. First, the gross effect of household poverty on the outcome of interest was examined, to test the hypothesis that youth from poor and extremely poor households were less likely than their nonpoor counterparts to use a condom at first sex. We used a second model to examine whether the result differed after controls for differences in youths' observed background characteristics were included. Control variables were selected on the basis of their theoretical importance in the area of adolescent reproductive health research. The poverty variables were tested for interaction with each of the control variables included in the final statistical model; none of the interaction terms were significant and therefore none were retained. Finally, we ran the full model, which included community-level random effects, to assess the association between poverty and condom use at first sex after cor- 


\begin{tabular}{|c|c|c|}
\hline Characteristic & $\begin{array}{l}\text { Male } \\
(\mathrm{N}=573)\end{array}$ & $\begin{array}{l}\text { Female } \\
(\mathrm{N}=605)\end{array}$ \\
\hline \multicolumn{3}{|l|}{ Poverty status* } \\
\hline Nonpoor & 53.2 & 44.3 \\
\hline Poor & 27.6 & 30.9 \\
\hline Extremely poor & 19.2 & 24.8 \\
\hline \multicolumn{3}{|l|}{ Age $^{*}$} \\
\hline $14-15$ & 7.2 & 4.6 \\
\hline $16-19$ & 58.8 & 52.2 \\
\hline $20-22$ & 34.0 & 43.1 \\
\hline \multicolumn{3}{|l|}{ Race* } \\
\hline African & 84.3 & 90.3 \\
\hline Othert & 15.7 & 9.8 \\
\hline \multicolumn{3}{|l|}{ Location } \\
\hline Urban & 78.8 & 80.1 \\
\hline Rural & 21.2 & 19.9 \\
\hline \multicolumn{3}{|c|}{ Lives with both parents**** } \\
\hline Yes & 40.8 & 30.3 \\
\hline No & 59.2 & 69.8 \\
\hline \multicolumn{3}{|c|}{ Feels closest to parent ${ }^{* * *}$} \\
\hline Yes & 52.7 & 62.2 \\
\hline No & 47.3 & 37.9 \\
\hline \multicolumn{3}{|c|}{ Currently enrolled in school**** } \\
\hline Yes & 62.1 & 44.5 \\
\hline No & 37.9 & 55.5 \\
\hline Total & 100.0 & 100.0 \\
\hline
\end{tabular}

recting for clustering within communities. The decision to stratify all multivariate models by sex was based on previous theoretical and empirical evidence that important differential poverty effects by gender exist. Testing the interaction between sex and poverty confirmed this choice.

In the full model, the random community effect corrects the estimates of the standard errors to account for clustering of adolescents within each community. For this study, a community was defined according to the administrative boundaries of each enumeration area described in the sampling process.

\section{RESULTS}

Of the sexually experienced young men in our sample, $53 \%$ were nonpoor, 28\% were poor and 19\% were extremely poor; the proportions for young women were $44 \%, 31 \%$ and $25 \%$, respectively (Table 1 ). Most males and females were aged 16-22 (93\% and 95\%, respectively), African (84\% and 90\%, respectively) and from urban areas (79\% and $80 \%$, respectively). More than half of young men and women reported not living with both of their parents (59\% and 70\%, respectively) and that a parent was the person to whom they felt closest (53\% and $62 \%$, respectively); the majority of males ( $62 \%$ ) were currently enrolled in school, whereas the majority of females (56\%) were not currently enrolled in school.
Overall, about a quarter of young people (23\%) had used a condom at sexual debut (Table 2); $31 \%$ of nonpoor youth did so, compared with $16 \%$ of poor and $14 \%$ of extremely poor youth. Smaller proportions of 20-22-yearolds than of $14-19$-year-olds (17\% vs. $26-27 \%$ ) and of African youth than of others (17\% vs. $61 \%$ ) protected themselves at first sex. Greater proportions of young people living in an urban area than of their rural counterparts ( $25 \%$ vs. $15 \%$ ) and of youth living in a two-parent household than of those not living with both parents (27\% vs. $20 \%$ ) reported having used a condom. Twenty-eight percent of young people who reported that the person to whom they felt closest was a parent had used a condom, compared with $18 \%$ of those who felt closest to someone else. A greater proportion of youth currently enrolled in school than of others had used a condom at first sex (27\% vs. $18 \%$ ).

In the unadjusted multivariate model, poor and extremely poor males had half the odds of their nonpoor counterparts of having used a condom at sexual debut (odds ratios, 0.5 each-Table 3, page 124); poor and extremely poor females had about one-third the odds of their nonpoor counterparts of having used a condom ( 0.4 and 0.3 , respectively). When background variables were included in the analyses, female respondents living in pover-

\begin{tabular}{|c|c|}
\hline Characteristic & $\begin{array}{l}\% \\
(\mathrm{~N}=1,178)\end{array}$ \\
\hline All & 22.7 \\
\hline \multicolumn{2}{|l|}{ Poverty status } \\
\hline Nonpoor & $30.7^{* * *}$ \\
\hline Poor & 15.7 \\
\hline Extremely poor & 14.2 \\
\hline \multicolumn{2}{|l|}{ Gender } \\
\hline Male & 20.9 \\
\hline Female & 24.3 \\
\hline \multicolumn{2}{|l|}{ Age } \\
\hline $14-15$ & $26.1^{* * *}$ \\
\hline 16-19 & 26.7 \\
\hline $20-22$ & 16.5 \\
\hline \multicolumn{2}{|l|}{ Race } \\
\hline African & 17.1 \\
\hline Other† & $61.1^{* * *}$ \\
\hline \multicolumn{2}{|l|}{ Location } \\
\hline Urban & $24.6^{* *}$ \\
\hline Rural & 15.3 \\
\hline \multicolumn{2}{|c|}{ Lives with both parents } \\
\hline Yes & $27.3^{*}$ \\
\hline No & 20.1 \\
\hline \multicolumn{2}{|c|}{ Feels closest to parent } \\
\hline Yes & $28.1^{* * *}$ \\
\hline No & 18.2 \\
\hline \multicolumn{2}{|c|}{ Currently enrolled in school } \\
\hline Yes & $26.7^{* *}$ \\
\hline No & 18.1 \\
\hline
\end{tabular}


TABLE 3. Odds ratios (and standard errors) from logistic regression analysis assessing the likelihood of using a condom at sexual debut, by gender, according to characteristics

\begin{tabular}{|c|c|c|c|c|c|c|}
\hline \multirow[t]{2}{*}{ Characteristic } & \multicolumn{3}{|l|}{ Male } & \multicolumn{3}{|l|}{ Female } \\
\hline & Unadjusted & $\begin{array}{l}\text { Background } \\
\text { factors }\end{array}$ & $\begin{array}{l}\text { Community } \\
\text { effects }\end{array}$ & Unadjusted & $\begin{array}{l}\text { Background } \\
\text { factors }\end{array}$ & $\begin{array}{l}\text { Community } \\
\text { effects }\end{array}$ \\
\hline Poor vs.nonpoor & $0.47(0.15)^{*}$ & $0.55(0.18) \dagger$ & $0.69(0.23)$ & $0.36(0.10)^{* * *}$ & $0.37(0.11)^{*}$ & $0.39(0.10)^{* * *}$ \\
\hline Extremely poor vs. nonpoor & $0.47(0.15)^{*}$ & $0.64(0.20)$ & $0.70(0.28)$ & $0.30(0.09)^{* * *}$ & $0.35(0.11)^{* * *}$ & $0.36(0.11)^{* * *}$ \\
\hline In school & na & $1.25(0.31)$ & $1.42(0.41)$ & na & $2.14(0.46)^{* * *}$ & $2.26(0.49)^{* * *}$ \\
\hline Urban & na & $1.84(0.70)$ & $2.35(1.25)$ & na & $1.36(0.38)$ & $1.58(0.56)$ \\
\hline Lives with both parents & na & $2.00(0.50)^{* * *}$ & $1.61(0.43)$ & na & $0.90(0.20)$ & $0.86(0.21)$ \\
\hline Feels closest to parent & na & $2.28(0.56)^{* * *}$ & $2.47(0.70)^{* * *}$ & na & $1.21(0.22)$ & $1.25(0.28)$ \\
\hline
\end{tabular}

ty continued to have lower odds of utilizing a condom at first sex (0.4 each); however, the odds for poor males became attenuated (0.6) and only marginally significant, whereas the odds for extremely poor males became nonsignificant. In the final model, which corrected for community clustering by adding random community effects to the background controls, poor and extremely poor females remained significantly less likely than nonpoor females to utilize condoms at first sex ( 0.4 each); there were no differences between poor and extremely poor males and their nonpoor counterparts.

\section{DISCUSSION}

Poverty and entrenched gender discrimination within cultural and social norms have been widely discussed as two of the main reasons women are disproportionately at risk of HIV in South Africa. 2,24,25 Our findings add evidence to a growing consensus that women's risk of HIV is disproportionately magnified by dire economic circumstances.

Comparing the results of our three analytic models reveals striking differences between males and females in the degree to which community factors influence poverty's adverse effect on condom use. Correcting for community clustering does not change the risk of unprotected first sex faced by women living in poverty. This result regarding young women's sexual risk-taking behaviors contrasts sharply with the findings for young men. The risk attributed to males living in poverty becomes nonsignificant after the inclusion of individual-level risk factors and correction for clustering in communities. However, a larger sample of extremely poor males might have reduced the standard errors of the estimates and found a significant difference.

The majority of the research literature on neighborhood factors has found that context does matter; however, most of these studies have been carried out in the United States. ${ }^{10-15,22,23}$ There remains a paucity of research on community or neighborhood effects in developing countries. Even scarcer is information regarding community's differential importance by sex and how it may affect impoverished youths' risk for adverse reproductive and sexual health outcomes, including HIV/AIDS. Although this study did not measure causal pathways through which community factors may affect (or in the case of females, not affect) the relationship between poverty and condom use among youth in South Africa, the theory and constructs of social disorganization provide some insight into what might be occurring. ${ }^{14}$ Unobserved community factors shared within neighborhoods appear to counteract, in part, the negative effect of poverty on condom use for young men. Such factors, however, do not appear to influence young women who come from impoverished homes to use condoms.

Although Kaufman et al. did not look specifically at the relationship between poverty and condom use, their findings underline a differential influence of community factors (based on aggregated individual-level variables) on condom use by gender. Perhaps most relevant to our results, Kaufman et al. found that several community-level variables (educational attainment, school enrollment, work status and involvement in sports activities) were actually negatively associated with males' condom use; however, females' condom use was positively associated with only one factor at the community level: average earnings per week. These findings echo the overall hypothesis and result of the current study: Poverty is the overreaching risk factor for increased HIV among young women in South Africa.

\section{Limitations}

There are a number of limitations that must be kept in mind when interpreting the results from this analysis. First, several assumptions are inherent in our measurement of poverty. A well-known shortcoming of means indicators of poverty, including household expenditures, is that they are proxies for an individual's own definition of poverty, and as such, do not capture all the information that is included in the true phenomenon, such as intrahousehold inequality. In addition, the accuracy of the poverty measures may have been compromised by some respondents' lack of knowledge, or simply their imperfect recollection of the exact amount spent by their household over the past month. Furthermore, underreporting or overreporting of condom use must be considered, given that data on sexual practices, particularly among adolescents, are known to be susceptible to reporting bias caused by societal norms.

Finally, it is difficult to delineate a community. As is common, we defined a community by its political or administrative boundaries, rather than by its residents 
themselves. The conceptual and methodological shortcomings of this method have been well-documented. ${ }^{14}$ It may be that the community processes being captured do not operate within the bonds delineated by the enumeration area. Although it is impossible to know if the neighborhood would be better represented according to a normative or social definition, the information provided in this study by looking at the relationship between community-albeit based on administrative data-and poverty addresses a documented void in the field of multilevel studies, particularly in developing countries. ${ }^{17}$

\section{CONCLUSIONS}

Poverty remains a central factor for a young woman's risk of HIV, even after controlling for shared characteristics within her community. The role of poverty in an individual's increased risk of HIV has long been a topic of interest for researchers in the prevention of HIV/AIDS, particularly among women. Although there is a documented link between poverty and HIV infection, less is known regarding exactly what types of poverty are most detrimental, especially for youth. In her article examining the asset vulnerability framework, Moser asserts that the conventional money-metric approach of using income or consumption as a proxy for poverty level may be too limited in scope. ${ }^{26}$ Like other researchers who have examined poverty's effects, Moser stresses the need to look at other types of assets, including those contextual variables often examined in neighborhood effects research that are thought to often have a positive effect, particularly for young women. Our results indicate, however, that the negative influence of household expenditure-based poverty measures on condom use at sexual debut for young women aged 14-22 in KwaZulu-Natal, South Africa, outweighs any overall positive influences that may be present in their community.

Future investigation of contextual effects should strive to explore the heterogeneity of young populations, including the differential effects of neighborhood constructs according to sex in the developing country context. This research should develop specific indicators to measure prevailing cultural and social norms at the structural level. In addition, researchers should strive to develop longitudinal surveys, expressly geared toward capturing these community constructs. This includes creating more sensitive measures of what constitutes a community for its residents, as well as testing specific indicators of communitylevel effects (often conceptualized under the theory of social disorganization). Although a number of studies have found that some community constructs based on administrative boundaries do in fact echo local interpretation of the same, there remains considerable debate of how to best capture the phenomenon. ${ }^{14,17}$ This is particularly true among the urban poor in developing countries, where definitions of community developed primarily in the United States may not apply.

\section{REFERENCES}

1. The Joint United Nations Programme on HIV/AIDS (UNAIDS), Report on the Global HIV/AIDS Epidemic, Geneva: UNAIDS, 2006.

2. Pettifor AE et al., Young people's sexual health in South Africa: HIV prevalence and sexual behaviors from a nationally representative household survey, AIDS, 2005, 9(14):1525-1534.

3. Stephenson J, AIDS in South Africa takes center stage, Journal of the American Medical Association, 2000, 284(2):165-167.

4. Farmer P, Connors M and Simmons J, Women, Poverty and AIDS, Monroe, Maine, USA: Common Courage Press, 1996.

5. Carter M and May J, One kind of freedom: poverty dynamics in post-apartheid South Africa, World Development, 2001, 29(12): 1987-2006.

6. Statistics South Africa (Stats SA), Measuring Poverty in South Africa, Pretoria, South Africa: Stats SA, 2000.

7. Gillies $\mathrm{P}$ et al., Is AIDS a disease of poverty? AIDS Care, 1996, 8(3):351-363

8. Guo $\mathrm{G}$ and Harries K, The mechanisms mediating the effects of poverty on children's intellectual development, Demography, 2000, 37(4):431-447.

9. Sen A, Development as Freedom, New York: Alfred A. Knopf, 1999.

10. Brooks-Gunn J et al., Neighborhood Poverty: Context and Consequences for Children, New York: Russell Sage Foundation, 1997.

11. Brooks-Gunn J et al., Do neighborhoods influence child and adolescent development? American Journal of Sociology, 1993, 99(2):353395

12. Coulton CJ et al., Community level factors and child maltreatment rates, Child Development, 1995, 66(5):1262-1276.

13. Coulton CJ and Pandey S, Geographic concentration of poverty and risk to children in urban neighborhoods, American Behavioral Scientist, 1992, 35(3):238-257.

14. Cantillon D, Community social organization, parents, and peers as mediators of perceived neighborhood block characteristics on delinquent and prosocial activities, American Journal of Community Psychology, 2006, 37(1/2):111-127.

15. Browning $C R$ et al., Neighborhood context and racial differences in early sexual activity, Demography, 2004, 4l(4):697-720.

16. Campbell $\mathrm{C}$ et al., The impact of social environments on the effectiveness of youth HIV prevention: a South African case study, AIDS Care, 2005, 17(5):471-478.

17. Montgomery MR and Hewett PC, Urban poverty and health in developing countries: household and neighborhood effects, Demography, 2005, 42(3):397-425.

18. Kaufman CE et al., Communities, opportunities, and adolescents sexual behavior in KwaZulu-Natal, South Africa, Studies in Family Planning, 2004, 35(4):261-274.

19. Turner AG et al., A not quite as quick but much cleaner alternative to the Expanded Programme on Immunization (EPI) Cluster Survey design, International Journal of Epidemiology, 1996, 25(1):198-203.

20. Stats SA, The People of South Africa Population Census, 1996, Pretoria, South Africa: Stats SA, 1998.

21. Gephart MA, Neighborhoods and communities as contexts for development, in: Brooks-Gunn J, Duncan GJ and Aber JL, eds., Neighborhood Poverty: Context and Consequences for Children, Vol. 1, New York: Russell Sage Foundation, 1997, pp. 1-43.

22. Upchurch DM et al., Neighborhood and family contexts of adolescent sexual activity, Journal of Marriage and the Family, 1999, 61(4): 920-933.

23. Upchurch D, First sex: individual, family, and neighborhood influences, paper presented at the annual meeting of the Population Association of America, Washington, DC, Mar. 29-31, 2001. 
24. Kelly K and Parker P, Communities of Practice: Contextual Mediators of Youth Response to HIV/AIDS, Pretoria, South Africa: Department of Health (Sentinel Site Monitoring and Evaluation Project for the Beyond Awareness Campaign), 2000.

25. Eaton L et al., Unsafe sexual behaviour in South African youth, Social Science \& Medicine, 2003, 56(1):149-165.

26. Moser C, The asset vulnerability framework: reassessing urban poverty reduction strategies, World Development, 1998, 26(1):1-19.

\section{RESUMEN}

Contexto: Es importante examinar si la juventud proveniente de familias en desventaja tienen menor probabilidad que otras de usar un condón en la primera relación sexual, aun después de corregir por características compartidas dentro de las comunidades.

Métodos: Se utilizó datos de la encuesta de línea de base de Transiciones a la Adultez en el Contexto del SIDA en Sudáfrica en KwaZulu-Natal. Se evaluó la relación entre pobreza y el uso del condón en la primera relación sexual en personas de 14-22 años mediante regresión logística con efectos aleatorios, con correcciones por características compartidas de los adolescentes dentro de cada comunidad.

Resultados: Veintitrés por ciento de las personas jóvenes habían usado condón en la primera relación sexual. Las mujeres pobres y extremadamente pobres tuvieron cerca de un tercio de las probabilidades de las mujeres no pobres de usar condón en la primera relación sexual, aun después de ajustar por conglomeración por comunidad; entre los hombres, sin embargo, no hubo asociación entre pobreza y uso del condón después de ajustar por factores del contexto y conglomeración por comunidad.

Conclusiones: En Sudáfrica, la pobreza, independientemente del contex to comunitario, continúa siendo un factor central de riesgo para el VIH entre las mujeres jóvenes, pero no para los hombres.

\section{RÉSUMÉ}

Contexte: Il importe d'examiner si les jeunes issus de ménages défavorisés sont moins susceptibles que les autres d'utiliser le préservatif lors de leurs premiers rapports sexuels, même après correction compte tenu des caractéristiques partagées au sein des collectivités.

Méthodes: L'analyse repose sur les données d'enquête de base de l'étude Transitions to Adulthood in the Context of AIDS in South Africa (Transitions vers l'âge adulte dans le contexte du sida en Afrique du Sud), menée au KwaZulu-Natal. Le rapport entre la pauvreté et l'usage du préservatif par les 14-22 ans lors de leurs premiers rapports sexuels, compte tenu des caractéristiques communes des adolescents au sein de chaque collectivité, est évalué par régression logistique d'effets aléatoires.

Résultats: Vingt-trois pour cent des jeunes avaient utilisé le préservatif lors de leurs premiers rapports sexuels. Pour les filles pauvres et extrêmement pauvres, la probabilité d'avoir utilisé le préservatif lors de leurs premiers rapports sexuels s'est avérée environ trois fois inférieure à celle relevée parmi leurs homologues non pauvres, même compte tenu de groupement communautaire. Côté masculin, aucune association entre la pauvreté et l'usage du préservatif n'a été observée compte tenu des facteurs contextuels et de groupement communautaire.

Conclusions: La pauvreté demeure un facteur de risque fondamental de contraction du VIH parmi les jeunes femmes en Afrique du Sud, indépendamment du contexte environnant. Elle ne l'est pas chez les hommes.

\section{Acknowledgments}

The authors thank Kate MacIntyre, Lisanne Brown, Anastasia Gage, John Lefante and Robert Magnani for their contribution to the development of this manuscript as a doctoral dissertation committee at Tulane University School of Public Health and Tropical Medicine.

Author contact:amararobinson@yahoo.com

\section{NOTE TO AUTHORS AND REVIEWERS}

\section{New Procedure for Submitting a Manuscript}

International Family Planning Perspectives now has an online submission process through Manuscript Central. This new system will streamline our procedures for handling the growing number of manuscripts that we receive and will enable authors to track the progress of their submissions. To submit a manuscript, go to $<$ http://mc.manuscriptcentral.com/ifpp $>$, and follow the instructions for uploading your paper and cover letter.

The Manuscript Central system will also be our main means of communicating with reviewers. Anyone who agrees to review a manuscript will be directed to the site for instructions on how to submit their review. 